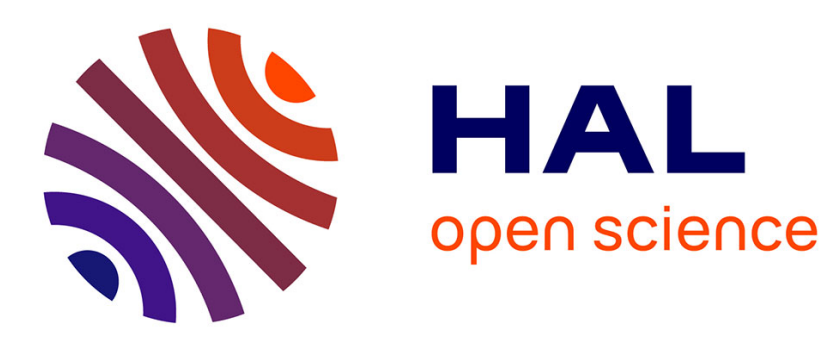

\title{
Chemicals and Environmental History
}

Nathalie Jas

\section{To cite this version:}

Nathalie Jas. Chemicals and Environmental History. Ambix, 2014, 61 (2), pp.194-198. 10.1179/0002698014Z.00000000053 . hal-02633941

\section{HAL Id: hal-02633941 \\ https://hal.inrae.fr/hal-02633941}

Submitted on 27 May 2020

HAL is a multi-disciplinary open access archive for the deposit and dissemination of scientific research documents, whether they are published or not. The documents may come from teaching and research institutions in France or abroad, or from public or private research centers.
L'archive ouverte pluridisciplinaire HAL, est destinée au dépôt et à la diffusion de documents scientifiques de niveau recherche, publiés ou non, émanant des établissements d'enseignement et de recherche français ou étrangers, des laboratoires publics ou privés. 
AMBIX, Vol. 61 No. 2, May, 2014, 194-198

\section{ESSAY REVIEW}

\section{Chemicals and Environmental History}

The Polluters: The Making of Our Chemically Altered Environment. By BENJAMIN Ross and Steven Amter. Pp. vi + 223, illus., index. University Press: Oxford. 2012. \$27.95. ISBN: 980-0-19-973995-0.

Technoscience and Environmental Justice. Expert Cultures in a Grassroots Movement. Edited by Gwen Ottinger and Benjamin R. Cohen. Pp. vi + 298, illus., index. MiT Press: Cambridge, MA. 20II. \$24.00. ISBN: 978-0-262-5I6I8-I.

DDT and the American Century. Global Health, Environmental Politics, and the Pesticide that Changed the World. By David KinKela. Pp. 254, illus., index. University of North Carolina Press: Chapel Hill. 20I I. \$34.35. ISBN: 978-0-8078-3509-8.

Agent Orange: History, Science, and the Politics of Uncertainty. By Edwin A. Martini. Pp. 320, illus., index. University of Massachusetts Press: Amherst \& Boston. 201 2. \$24.95. ISBN: 978-I-55849-975-I.

Common Ground: Integrating the Social and Environmental in History. Edited by GENEvIÈve Massard-Guilbaud and Stephen Mosley. Pp. 404, illus., index. Cambridge Scholars Publishing: Newcastle. 20I I. \$74.99. ISBN: 978-I-4438-2549-8.

A recent report by the United Nations Environment Programme (UNEP) showed that toxic chemical substances are responsible for 4.9 million deaths every year, i.e. 8.9 per cent of annual deaths. This report also highlights the fact that these figures are largely underestimated, given the significant knowledge gaps. Not only is the number of deaths and diseases caused by pollutants unknown, but most of the very large number of chemical substances in circulation have not been even minimally investigated for potential toxicity. ${ }^{\mathrm{I}}$ The first four of these five books, and certain chapters of the last one, provide important contributions to the growing historical and sociological literature on toxicants and their governance. This literature sheds light on the paradox of the increasingly massive development of (potentially) toxic chemical substances for over a century: while knowledge - especially scientific knowledge - of these substances has been continually expanding, movements denouncing them have constantly evolved, and complex regulatory systems to prevent and improve the substances' effects have been gradually developed. The books presented here provide insightful and detailed analysis of several major issues underpinning the literature on environmental chemicals. I shall present the five reviewed books focusing on four of those issues.

\footnotetext{
See Philippe Grandjean, Mette L. Eriksen, Ole Ellegaard and Johan A. Wallin, "The Matthew Effect in Environmental Science Publication: A Bibliometric Analysis of Chemical Substances in Journal Articles," Environmental Health Iо (2011): 96.
} 


\section{The production of scientific knowledge}

The first four books all address the scientific objectification of the harmful effects produced by toxic substances, each from a specific angle. Edwin A. Martini's book on Agent Orange probably provides the most in-depth discussion. This book makes a crucial contribution to the analysis of the complexity of scientific objectification of a substance's toxicity and/or of these deleterious effects, which are both biological and social. Producing scientific knowledge of the deleterious effects of a toxic chemical as dangerous as the TCDD dioxin, present in defoliants used from I 964 to I 973 during the Vietnam War, was in no way an easy task. Existing toxicological research and epidemiological studies carried out over the last thirty years contradict one another and do not offer conclusive evidence. Martini shows that beyond the scientific challenges raised by this type of research, the scientific uncertainty regarding the relationship between the significant presence of dioxins and the pathologies observed in veterans, as well as in the large number of Vietnamese children with congenital malformations, is rooted in complex historical, political and social processes. He closely retraces the construction of multiple lasting illusions of the safety of Agent Orange over time and in different scientific, political, administrative and judiciary bodies. He highlights how the existence of many scientific uncertainties and scientists' inability to reach conclusions in certain situations both encouraged and contributed to producing or reinforcing a number of major factors. In particular, these included the characteristics of US tort law, the precedent set by the Australian treatment of the veteran issue, the logic underpinning of the reparation systems set up in the USA for veterans, and the impossibility, for political and financial reasons, for Vietnamese citizens to take their cases to court or to fund the necessary toxicological and epidemiological work.

\section{Knowledge, intentionality, industry and state responsibility}

One of the great achievements of Martini's book, along with that of David Kinkela on DDT, was to show how detailed, multi-situated historical studies of a chemical's journey add considerable complexity to actors' accounts. This is particularly visible when the two authors answer the question that underlies many similar studies on toxic issues: that of responsibility for contaminations and, by extension, of liability for health and environmental damages. The issue is related to two additional interdependent questions: that of the knowledge of potential or known effects held by the people and institutions that allowed for the colossal dumping of potentially dangerous chemical substances into the environment; and that of their intentionality.

Martini and Kinkela show that the decisions on the large-scale use of the chemical substances that they studied were imbedded in complex historical processes, particularly surrounding the Cold War, US imperialist foreign policies and the development of international organisations. This complex scenario makes it impossible to provide 
simple answers concerning the intentionality and responsibility of states and international organisations. However, both books highlight the fact that the arrogance and short-sightedness of governments, political advisers, administrations, international organisations and multinationals were revealed by the material properties of the substances and of the biological organisms affected by them. Once released into the environment in large quantities, these substances turned into "unruly technologies," to use Jody Roberts' expression, namely technologies whose behaviours and effects were impossible to predict. Dioxin TCDD and DDT alike persist in both organisms and the environment with no possibility of eliminating them. The harmful effects of dioxins can appear in exposed individuals' descendants for several generations. After some initial success, the mass use of DDT led to DDT resistance in insects, which exacerbated malaria problems and further complicated vector control for public health and anti-insect strategies in agriculture, etc. These irreducible material properties of the chemical substances, and the ensuing health and environmental effects, were either unforeseen or poorly anticipated by political authorities.

The question of intentionality is central to Benjamin Ross' and Steve Amter's book. This book contributes to recent historical studies describing how different industries concealed information on the dangerousness of their products, effluents or waste. Ross and Amter retrace the history of the development of the US chemical industry between the late nineteenth century and the I970s. They draw on archives to show how this industry implemented multiple strategies to avoid being held responsible for health and environmental effects. These strategies included withholding information on the dangerousness of different types of pollution; controlling the activity of the organisations in charge of pollution regulation; lobbying to compromise certain researchers' work that was deemed problematic; and, finally, organising and sustaining public controversies to sow doubts about the deleterious effects of industrial pollution and contaminations. Some of these strategies concern one of the major questions on toxic issues: the capacity of regulatory systems to produce and use sufficiently unbiased knowledge.

\section{Regulatory knowledge}

Since the I970s, many scholars have documented examples of biases in the systems regulating chemical substances, products and industries. In most cases, these biases favoured economic imperatives at the expense of public health and environmental protection. For instance, in the volume edited by Massard-Guilbaud and Mosley, Jean-Baptiste Fressoz and Thomas Le Roux describe "the great transformation of French pollution regulation" between $\mathrm{I} 700$ and I 840 and unveil the aim of "protecting industry and commodifying the environment." Other similar studies have paid attention to the biases found in expert knowledge produced and mobilised in regulatory systems. The book edited by Gwen Ottinger and Benjamin R. Cohen directly tackles this question in a very original way. While the editors acknowledge 
the existence of biases in administrative and regulatory arenas, they argue that there is "room for manoeuvre," that is, possibilities to transform production and use of knowledge in order to support the interests of those people who are affected by pollution and contaminations. The different case studies in the book provide a fascinating and convincing account of these processes, even if some authors did not share the editors' enthusiasm and sometimes question the likeliness of the required transformations. Raoul Liévanos, Jonathan London and Julie Sze's chapter is particularly insightful in this respect. They study "the history of interactions" between regulatory and social movement organizations, showing how it shaped the way in which "both attempt to transform pesticide monitoring" in California. The authors describe an "uneven process by which environmental justice movements have transformed different spheres of science as practiced by social movement organizations and some of their target regulatory agencies." Their study highlights how the neoliberal transformations underway, which weakened regulatory agencies in favour of voluntary, market-based solutions, constrained these attempts to obtain environmental justice.

\section{Invisible people, lay and street knowledge and activism}

Most of the chapters in the volume edited by Ottinger and Cohen present "invisible" people, those who are neither seen nor heard, but who are often the first victims of contaminations. All the reviewed books contribute to making them visible in at least three different ways. First, these populations are implicitly present in the discourses of the actors studied: scientists, experts, administrative, political and industrial actors, NGOs, etc. Many chapters discuss the production and use of knowledge by these different actors and the controversies over the different understandings of the invisible populations. This type of analysis is particularly present in the books of Martini on Agent Orange and Kinkela on DDT. Second, certain populations are studied as they seek collective recognition of the offences inflicted on them. The analyses then focus on the forms of objectivation of offences used to support the claims of these social movements. Different processes appear: the intimate body experience of illness informing and shaping lay knowledge; more or less visible associations with engineers and scientists who provide counter-expertise; or the elaboration, often with the help of NGOs, of alternative systems of objectivation of offences. Lucienne Néraud's chapter in the book Common Ground retraces the history of the United Farmworkers, the trade union representing Mexican and Mexican-American campesinos in Texas between I966 and I986, whose main concern was the health effects of dangerous pesticides. United Farmworkers lobbied for working conditions with limited exposure but also for the right of farmworkers to be informed about the pesticides and their toxicity. Third, the invisible populations also appear in the analyses of the systems set up by NGOs or social scientists to both make these populations visible and give them a voice in the scientific productions or the regulatory knowledge which affects them. In the book 
Technoscience and Environmental Justice, the chapter by Maria and Jim Powell shows how "community participation" mechanisms can allow ignored minorities to reorient scientific risk assessment systems whose tools sometimes conceal the involved risks because particular social and cultural features are not taken into account. In the same book, the chapter by Jaclyn Johnson and Darren Sanco follows a similar approach suggesting that an effective reorientation of scientific risk assessment in a direction more favourable to these minorities would require an impossible "redistribution of power," a very improbable situation which makes so difficult the long-term permanence of innovative experiences.

All things considered, the reviewed books provide a highly valuable insight into the multiple problems raised by chemical products once they have left the confined realms of laboratories and research institutions. Using different approaches and historical cases, the authors offer good examples of how social sciences and humanities can contribute to a better understanding of these issues while sometimes providing hints for future solutions. 